\title{
Retratos profanados: uma análise sobre morte e fotografia na poesia de Carlos Drummond de Andrade
}

1 Doutoranda em Letras na Universidade Federal de Pelotas (UFPel). Professora do Instituto Federal https://orcid.org/0000-0002-0126-8063

E-mail: marianerocha@gmail.com

2 Doutor em Letras pela Universidade Federal do Rio Grande do SUl (UFRGS). Professor litular do Rio Grande do Sul (UFRGS). Professor titular do Federal de Pelotas (UFPel).

http://orcid.org//0000-0002-0590-1890

E-mail: aulus.mm@gmail.com

Recebido em: 2/1/2019

Aprovado em: 18/6/2019.

Endereços dos autores: Rua Gomes Carneiro, 1, Centro, Pelotas, RS, CEP
96010-610.

Corredor das Tropas, 801, Jaguarão, RS, CEP: 96300-000.
Profanated portraits: an analyze about death and photograph in Carlos Drummond de Andrade's poetry

Mariane Pereira Rocha ${ }^{1}$ Instituto Federal Sul-rio-grandense, Jaguarão, RS, Brasil.

Aulus Mandagará Martins ${ }^{2}$

Universidade Federal de Pelotas, Pelotas, RS, Brasil.

\section{RESUMO}

0 presente artigo tem como objetivo identificar as funções que a fotografia desempenha na relação que o eu-lírico drummondiano estabelece com a morte nos poemas "Os mortos", de Lição de coisas (1962), "Os mortos de sobrecasaca”, de Sentimento do mundo (1940), "Os rostos imóveis", de José (1940) e "Necrológio dos desiludidos do amor", de Brejo das almas (1932). Parte dos estudos de Giorgio Agamben (2007), Susan Sontag (2004), Georges Didi-Huberman (1998) e Joan Fontcuberta (2010), utilizando a metodologia bibliográfica na perspectiva dos Estudos Comparados. Discute-se, assim, que a fotografia, enquanto temática drummondiana, vai na contramão do discurso comum sobre a fotografia no qual ela é vista como uma mera representação da realidade ou como um registro fiel e confiável do passado. Dessa forma, ela vai se apresentar como um dispositivo frágil e que constantemente o relembra da impossibilidade da permanência da memória, contribuindo para um contínuo desencontro do eu-lírico com os mortos, que se manifesta em um tom irônico e de afronta, bem como em uma dificuldade de elaborar o passado.

Palavras-chave: Fotografia. Morte. Carlos Drummond de Andrade.

\section{ABSTRACT}

The purpose of this article is to identify the functions that photography plays in the relation that Drummond's lyric self establishes with death in the poems "Os mortos" from Lição de coisas (1962), "Os mortos de sobrecasaca" from Sentimento do mundo (1940), "Os rostos imóveis" from José (1940) and "Necrológio dos desiludidos do amor" from Brejo das almas (1932),using the perspective of Giorgio Agamben (2007) Susan Sontag (2004), Georges Didi-Huberman (1998) and Joan Fontcuberta (2010). The methodology we use is the bibliographic one from the comparative studies perspective. This paper argues that photography, as a Drummond theme, will go against the common discourse on photography, in which it is seen as a mere representation of reality or as a faithful and reliable record of the past. Thus, it will present itself as a fragile device which constantly reminds him of the impossibility of permanence of memory, contributing to a continuous mismatch between the lyrical self and the dead, which is expressed in an ironic and defiant tone, as well as in a difficulty of elaborating the past.

Keywords: Photography. Death. Carlos Drummond de Andrade. 


\section{Introdução}

o folhear rapidamente qualquer um dos tantos livros de poesia de Carlos ADrummond de Andrade notamos facilmente a ausência de fotografias e imagens ao longo das páginas. Salvo algumas exceções, em que o editor opta por incluir alguma foto do poeta mineiro na apresentação do autor, sozinho, com sua família ou com amigos, os poemas em si não incluem fotografias. 0 convívio entre texto poético e texto fotográfico na mesma materialidade - a página do livro - seria, contudo, apenas uma possibilidade de diálogo entre poesia e fotografia. Outra possibilidade seria a ausência da fotografia enquanto materialidade, mas que se torna visível ao leitor através da leitura que o eu-lírico faz da mesma. Nesse sentido, o poema incorpora a fotografia, através tanto da sua mera descrição quanto da apropriação de elementos inerentes ao ato fotográfico. É dessa forma que vamos encontrar em Drummond uma poesia que é intimamente perpassada pelo visual, pelo olhar e pelo ver e, especialmente, pela fotografia. Nos poemas drummondianos, não temos acesso direto às fotografias, mas sim às percepções e às leituras que o eu-lírico faz delas.

Silviano Santiago (2007), em introdução à Poesia completa de Carlos Drummond de Andrade, afirma que o poeta não era somente um excelente leitor de livros e jornais, mas também um exímio leitor de imagens, especialmente de fotografias. De acordo com o autor, "os olhos do poeta não funcionam como os de um crítico de arte profissional. Vão diretamente ao detalhe que dá forma e sentido ao filme, ao quadro, à escultura ou à fotografia, e que, para ele, passa a servir de clarão que ilumina o todo" (SANTIAGO, p. 21). Nesse sentido, frequentemente encontramos em Drummond um eu-lírico leitor de fotografias, que a partir da observação de um retrato ou ainda de um álbum de fotografias, tenta elaborar o passado, organizar as suas memórias e reconstituir as suas lembranças.

Além disso, percebemos existir ainda uma relação recorrente e significativa entre fotografia e morte na poesia de Drummond, já que as fotografias que o eu-lírico observa são constantemente retratos de pessoas que já morreram. São mortos que foram fotografados durante a vida, cujos retratos agora assumem uma importância diferente daquela que tinha quando foram tirados, se ressignificam através do tempo. Mais do que objetos que permitem ou desencadeiam a rememoração dos mortos, elas parecem ser o local em que o eu-lírico drummondiano elabora as suas reflexões sobre morte e passagem do tempo, bem como sobre a própria função do dispositivo fotográfico.

Nesse viés, o presente trabalho se propõe a analisar os poemas "Os mortos", de Lição de coisas (1962), “Os mortos de sobrecasaca”, de Sentimento do mundo (1940), “Os rostos imóveis", de José (1940) e "Necrológio dos desiludidos do amor", de Brejo das almas (1932); todos textos em que, de diferentes modos, o eu lírico drummondiano se utiliza de fotografias para propiciar uma reflexão sobre a morte. Como objetivos gerais, busca-se investigar a relação entre a morte e a fotografia nos poemas analisados e tentar compreender como tal relação afeta as percepções do poeta sobre os movimentos de lembrar e esquecer. Espera-se ainda que essa análise seja uma ferramenta importante para verificar como a fotografia opera na preservação de uma memória que, em Drummond, se apresenta incerta e frágil, bem como para discutir de que forma a noção da impossibilidade de apreensão da totalidade do passado através da memória afeta a constituição da lírica drummondiana.

\section{Fotografia e morte}

De acordo com Boris Kossoy (2014), uma fotografia permite a existência de dois tempos: o tempo da criação, quando a fotografia é feita, momento em que um instante é retirado de seu continuum e registrado, e o tempo da representação, todo o período posterior em que a fotografia será exibida. Segundo ele, esses tempos seriam, respectivamente, o efêmero - visto que a criação é fruto de apenas um momento, um fragmento de instante - e o perpétuo - para sempre exibindo e retomando o tempo da criação. De acordo com o autor:

O tempo da criação se refere ao próprio fato, no momento em que este se produz, contextualizado social e culturalmente. É, no entanto, um tempo efêmero, que desaparece, volatiliza-se, está sempre no passado, insistentemente. No tempo da representação, os assuntos e fatos permanecem em suspensão, petrificados eternamente, perpétuos se conservados: peças arqueológicas, cuja poeira do tempo removemos cuidadosamente, na tentativa de descortinarmos as sucessivas camadas que constituem sua espessura histórico-cultural, sua memória (KOSSOY, 2014, p. 135). 
Nesse sentido, podemos pensar que o tempo da criação, em certa medida, indica uma aproximação entre o fazer fotográfico e a morte. Conforme reflete Joan Fontcuberta, a fotografia é um agente que mata "a vida das coisas". Segundo ele "através do visor, qualquer parte de mundo se transfigura necessariamente em uma natureza-morta, um retalho de natureza inquietantemente parada, inerte" (2010, p. 48). Não é à toa que, tão frequentemente, os verbos associados ao ato fotográfico sejam "congelar" ou "eternizar": é como se a câmera, ao capturar uma ação, de certa forma, a condenasse a uma rigidez, já que durante muito tempo a exibirá da mesma maneira, enquanto a materialidade fotográfica durar³.

De maneira similar, é possível também identificar a relação do tempo de representação com a morte, já que a fotografia, enquanto produto, segundo Susan Sontag, é um atestado de nossa mortalidade, uma vez que "as fotos mostram as pessoas incontestavelmente presentes num lugar e numa época específica de suas vidas; agrupam pessoas e coisas que, um instante depois, se dispersaram, mudaram, seguiram o curso de seus destinos independentes" (2004, p. 44).

Dessa forma, percebemos que a fotografia, em seu gesto duplo de ato fotográfico e de produto, se aproxima da morte, antes de se interessar por ela enquanto tema, por sua natureza, pelo seu fazer e pelo resultado dessa prática. Na reflexão de Sontag (2004), notamos que muito dessa proximidade entre morte e fotografia parece vir da capacidade da segunda em evidenciar a passagem do tempo:

Por meio das fotos, acompanhamos da maneira mais íntima e perturbadora o modo como as pessoas envelhecem. Olhar para uma velha foto de si mesmo, de alguém que conhecemos ou de alguma figura pública muito fotografada é sentir, antes de tudo: como eu (ela, ele) era muito mais jovem na época (SONTAG, 2004, p. 44).

Aqui se faz importante mencionar que a materialidade fotográfica, seja ela um negativo, uma foto impressa ou fotografia digital, não é tão durável quanto o senso comum costuma acreditar. Conforme nos lembra Didi-Huberman (2018) não podemos falar de imagens sem falar de cinzas: "Nós sabemos bem que cada memória é sempre ameaçada pelo esquecimento, cada tesouro é ameaçado pelo saque, cada tumba é ameaçada pela profanação. Por esse motivo, cada vez que abrimos um livro - pouco importa se o Gênesis ou os 120 dias de Sodoma -, teríamos talvez que reservar alguns segundos para refletir sobre as condições que tornaram possível o simples milagre de que esse texto esteja aqui, diante de nós, que tenha chegado até nós. Tantos livros e bibliotecas foram queimados. E da mesma forma, cada vez que colocamos nosso olhar sobre uma imagem deveríamos pensar nas condições que impediram sua destruiç̃ao, seu desaparecimento. É tão fácil, tem sido tão recorrente, em qualquer época, destruir as imagens" (DIDI-HUBERMAN, 2018, p. 34).
Ao observar um retrato, assim, o que fica manifesto é o intervalo existente entre o tempo da criação e o tempo da representação ${ }^{4}$ e a forma como os referentes, especialmente os humanos, se modificam nesse ínterim, atestando assim a maneira como envelhecemos e nos recordando, dessa forma, de nossa mortalidade.

Além dessa relação entre morte e fotografia que se apresenta a partir da natureza fotográfica, vamos perceber também que a morte sempre foi uma temática presente nas fotos. Como um exemplo, destaca-se o hábito de fotografar pessoas mortas, que ocorre logo a partir do surgimento da fotografia. Essa, ainda pouco popularizada, tinha custos muito altos, de forma que mesmo as famílias com mais dinheiro, frequentemente podiam pagar apenas por um único retrato de seus familiares. Dada as grandes taxas de mortalidade, especialmente de mortalidade infantil, muitas vezes a única oportunidade de fotografar um ente querido era na ocasião de sua morte. Sandro Blume explica que

Ao retratar um ente querido em seu ataúde, a imagem traduzia o desejo de perenidade e congelamento do momento pós-morte, retendo a face da boa morte, ao mesmo tempo em que ajudava a reduzir a dor da perda. Geralmente se recorria de forma mais emblemática às fotografias pós-morte quando o falecido ainda não tinha sido retratado em vida (BLUME, 2003, p. 2).

Ainda nesse sentido, Luiz Vailati (2006) demonstra através da análise de fotografias de crianças mortas do século XIX em São Paulo que, para as famílias, quando uma criança falecia, tinha-se a noção de que em função de uma pureza específica da infância, ela iria diretamente aos céus, estabelecendo contato com anjos e deuses. Dessa forma, tirar fotos desse momento não era algo que, posteriormente, iria provocar dor, não era visto como algo mórbido ou macabro, mas ao contrário, recordava os pais e familiares de que aquela havia sido uma morte abençoada e, ainda, demonstrava todos os cuidados

4 Vale observar que a fotografia digital diminuiu drasticamente o tempo de espera entre o tempo de criação e o tempo de representação, já que nas câmeras que utilizavam filme, existia uma espera significativa enquanto as fotografias eram "reveladas". De acordo com Fontcuberta "a fotografia fotoquímica tradiciona impunha um tempo, um intervalo angustiante entre o clique e a experiência consumada da imagem e, durante esse adiamento, intervinha a projeção da ilusão e do desejo. Isso desaparece com a velocidade. Frente a essa dissolução emerre um sentimento de perda que vai além da questão poética e simbólica, um aspecto que corresponde também à possibilidade de reter a lembrança" (2010, p. 46). 
que os pais tiveram nos ritos funerários, já que as fotos eram frequentemente adornadas com flores, imagens e roupas de santos. Ele elucida que

fotografia do "anjinho" não apenas recorda um evento que era fundamental na afirmação da família perante a sociedade (cujo investimento material e simbólico tinha papel estratégico nisso), mas permite o exercício da celebração da unidade familiar, ao registrar um acontecimento cuja periodicidade dá lugar aos reencontros que reforçam a identidade da comunidade de sangue (VAILAITI, 2006, p. 64).

Ao mesmo tempo, o autor sinaliza a existência de fotos da mesma época que demonstram outras maneiras de lidar com a morte, em que o luto e sofrimento da família são mais valorizados, tornando-se o foco das celebrações fúnebres. Vailati (2006) afirma que a diferença entre essas fotografias e as anteriores era que, no primeiro caso, as fotografias representavam o novo estatuto espiritual da criança - a morte - e, no segundo caso, o objetivo parece ser preservar os aspectos que a criança tinha enquanto viva, ao mesmo tempo em que serve de objeto para rememoração da relação da criança com a família.

No decorrer das décadas, as fotografias da morte se tornam tabu, pela predominância da interpretação das mesmas como lembretes dolorosos da mortalidade e da perda. Vailati (2006) ainda acrescenta que o barateamento da fotografia e a possibilidade de fotografar os indivíduos em vida são fatores significativos para o desaparecimento das fotografias das pessoas mortas: "A presença - nos cemitérios paulistanos e cariocas, em túmulos de crianças das primeiras décadas do século XX - de fotografias destas quando vivas e nas mais variadas idades, não deixa de vir em apoio a essa última constatação" (VAILATI, 2006, p. 64). Assim, a partir do século XX o ato de fotografar pessoas mortas deixa de ser uma prática usual, assim como aquelas fotografias feitas no século anterior deixam de ser reproduzidas em álbuns familiares e acervos particulares e públicos. Sobre isso, Blume explica:

Se no momento em que tais fotografias foram elaboradas, encontra-se presente todo um esforço visando perpetuar uma imagem bela do morto, nos dias de hoje fica nítida uma relativa carga de constrangimento de parte das famílias que possuem em seu acervo tais fotografias.
Possivelmente em função de tornar público algo que consideram de teor macabro e, percebido como tabu nos dias de hoje. Igualmente aos olhares contemporâneos, a fotografia mortuária parece prolongar a dor, sendo percebida, até mesmo pelas famílias que preservam tais fotografias como uma atitude mórbida, em função de fixar a morte como elemento de recordação (2003, p. 2-3).

Há, ainda, outra possibilidade de diálogo entre fotografia e morte: os retratos feitos, durante a vida, de pessoas que estão agora mortas. São fotografias que possibilitam que se veja o rosto daqueles que não estão mais presentes, objetos de rememoração que recebem um lugar especial na casa dos vivos, e para os quais se volta quando se deseja prolongar a permanência da imagem daqueles que partiram. No México, por exemplo, no Día de los muertos, feriado comemorado para honrar os entes queridos que já morreram, os familiares constroem altares para seus mortos. Nesses altares, juntamente com comidas e bebidas, velas e outros acessórios, é costume incluir uma fotografia da pessoa falecida, já que eles acreditam que somente assim ela conseguirá realizar a sua passagem do mundo dos mortos para o mundo dos vivos durante a noite de comemorações. A fotografia, aqui, é carregada de poder simbólico, uma vez que ao ilustrar a imagem da pessoa que já se foi e, assim, permitir que os familiares relembrem desse ente querido, ela possibilita que o convívio com o morto seja estendido, tanto na instância da memória, quanto na instância espiritual, de acordo com suas crenças.

Georges Didi-Huberman elucida que há uma necessidade de preencher a ausência dos rostos que não estão mais presentes e que essa começa desde a préhistória ${ }^{5}$, quando diferentes povos realizavam rituais com os crânios das pessoas mortas, alterando-os e, algumas vezes até mesmo mantendo-as nas casas das famílias, "incisados, trepanados, seus orifícios frequentemente aumentados ou artificialmente fraturados, os crânios pré-históricos demonstram uma atenção extrema dada ao destino dos rostos" (1998, p. 70).

Didi-Huberman ainda enfatiza que "muitas vezes foi dito que, na época pré-histórica, o rosto humano não existia, que, em todo caso, era desprovido de significação, ou até que era afetado por um tabu" (DIDI-HUBERMAN, 1998, p. 64), já que a arte produzida por esses povos prioritariamente reproduzia corpos humanos e animais, raramente seus rostos. 0 autor problematiza, contudo, que não é porque algo não fo representado mimeticamente que ele não está lá, o que o direcizana às análises dos crânios como outro tipo de signo, esses mostrando a urgência da tentativa de estender a permanência dos rostos. 
De acordo com Didi-Huberman, essas práticas de manipulação dos crânios e o respectivo cuidado com os seus destinos - os crânios seriam preservados, cultuados e algumas vezes ainda consultados a respeito da vida, como se fossem oráculos - dizem muito sobre as funções que os retratos dos entes queridos viriam a desempenhar mais tarde. Segundo ele, o que é interessante nesse paralelo entre o trabalho com as caveiras e a fotografia é essa

maneira sistemática como o rosto ausente volta, de um modo ou de outro - mas sempre de maneira visual - ao lugar que de quem o enfeita para melhor apresentá-lo. Investigar um lugar para a perda do rosto nada mais é do que arranjar um lugar para que essa ausência se torne eficaz (DIDI-HUBERMAN, 1998, p. 76).

Observamos, assim, que as fotografias dos mortos parecem não carregar tão fortemente um valor de exposição, mas sim ter o seu valor de culto acentuado ${ }^{6}$, já que mantêm algo de ritualístico, uma vez que as pessoas vivas intencionam preservar a ligação com aqueles que já se foram através dessas fotos, tentando assim processar suas mortes e entender suas ausências. Dessa forma, tanto no trabalho com os crânios quanto no retrato "o rosto ausente, convertido em figura local da memória, não terá sido enfeitado senão para voltar e se aproximar sempre mais do rosto dos sobreviventes" (DIDI-HUBERMAN, 1998, p 76).

É nesse sentido que o autor afirma que o papel desses retratos vai muito além da mera representação dos mortos. De acordo com ele "o que os retratos fariam, depois de tudo, seria apenas poetizar - isto é, produzir - uma tensão sem recurso entre a representação dos rostos e a difícil gestão de sua perda" (DIDI-HUBERMAN, 1998, p. 62).

Walter Benjamin, ao contrapor o valor de culto ao valor de exposição, afirma que: "Na fotografia, o valor de exposição começa a suplantar totalmente o valor de culto. Este, porém, não desaparece sem resistência. Possui uma última defesa, que é o rosto humano. [...] É no culto da recordação de entes queridos distantes ou desaparecidos que o valor de culto do quadro encontra o seu último refúgio. É na expressão fugaz de um rosto humano nas fotografias antigas que a aura acena pela última vez (BENJAMIN, 2017, p. 22).

Letrônica | Porto Alegre, v. 12, n. 3, jul.-set 2019: e32863

\section{Os mortos profanados}

No poema "Os mortos", de Lição de coisas (1962), com apenas uma estrofe composta de seis versos, é possível visualizar a relação singular que o eulírico drummondiano estabelece com os retratos:

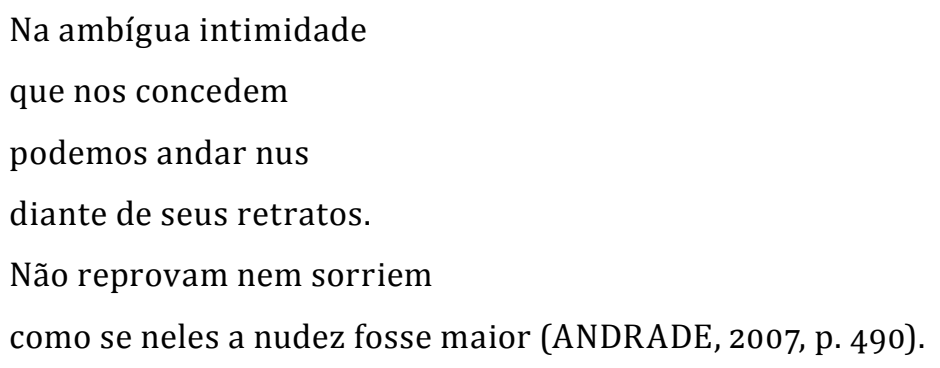

0 primeiro indício que temos sobre as pessoas retratadas manifesta-se no título, uma vez que antes de adentrar o poema, já sabemos que ele tratará de pessoas mortas. Ao longo dos versos, o eu-lírico não especifica quem são as pessoas retratadas da mesma forma que faz em outros poemas, aqui entendemos que se trata da família pelo contexto no qual os retratos se encontram, um lugar provavelmente doméstico, já que se tem a possibilidade de andar nu diante das fotografias. Além disso, as fotografias dessa época frequentemente representavam os membros da família e, conforme Sontag, o uso popular mais antigo da fotografia era justamente o de "comemorar as conquistas de indivíduos tidos como membros da família", já que "as câmeras acompanham a vida da família" (2004, p. 11). Aliado a isso, notamos que o poema é escrito na primeira pessoa do plural, como se o eu-lírico estivesse se incluindo em um grupo e visse a si mesmo como pertencente a ele, sustentando assim nossa hipótese de que se tratam de familiares, convivendo em um mesmo espaço doméstico.

o que causa certo estranhamento neste poema, contudo, é o elemento da nudez, inserido no terceiro verso, quando o eu-lírico afirma ser possível andar nu diante dos retratos dos mortos. A imagem poética da nudez carrega significados múltiplos e, se por um lado evidencia uma noção de liberdade, de poder se sentir à vontade e confortável, sem as amarras que a sociedade impõe, revelando assim certa autenticidade por parte daqueles que estão sem 
roupa, por outro lado destaca também a falta de proteção e a vulnerabilidade daqueles que estão nus. Outro sentido bastante manifesto que a nudez traz à tona é o de afronta às regras da sociedade, ou seja, a nudez como algo moralmente reprovável: estar nu, assim, seria uma espécie de desrespeito às normas de boa conduta social. No primeiro verso de "Os mortos", o eu-lírico diz que aos vivos é concedida uma "ambígua intimidade" e essa ambiguidade parece permear os sentidos da nudez expressos no poema.

Em uma primeira instância, então, são os vivos que andam nus em frente aos retratos. Entendendo o ato de andar nu enquanto esse gesto de rebeldia e desacato, os vivos desse poema parecem desrespeitar os mortos pelo simples fato de estarem vivos e, ao invés do lamento e luto destinado aos mortos, eles estão desfrutando a vida - o que nos remete a outro sentido da nudez, a sensualidade - sentindo prazer, tudo aquilo que não é mais permitido aos mortos. Mais tarde, porém, descobrimos que os mortos não reprovam a atitude do eulírico, tampouco sorriem, "como se neles a nudez fosse maior". Vamos observar, assim, que os mortos também estão afrontando os vivos, de acordo com o eulírico, ainda mais do que os vivos os desafiam, já que neles a nudez é "maior". Essa afronta cometida pelos falecidos retratados parece vir justamente da sua condição de mortos que insistem em permanecer vivendo na casa, se recusam a serem esquecidos, continuam pendurados na parede ou expostos na estante. Enquanto a morte deveria ser o fim da existência deles, eles seguem existindo através das imagens que constantemente relembram os vivos da finitude da vida, do prazer que está sempre prestes a acabar. Assim, encontramos no poema "Os mortos" a sugestão de que a fotografia é, por si só, uma afronta, já que além de agir como este constante lembrete do envelhecimento e da perenidade da vida, ela é também um desafio às regras naturais do esquecimento, já que ao fotografar alguém, estende-se a permanência dos rostos e dá-se a oportunidade de rever a imagem daqueles que já se foram, quando o percurso natural seria que aos poucos, essa imagem se desvanecesse na memória dos vivos.

Roland Barthes reflete que a fotografia tem o poder de transformar o sujeito em objeto e "até mesmo, se é possível falar assim, em objeto de museu" (1984, p 26). Esse raciocínio aponta para o diálogo já mencionado entre fotografia e morte, que surge a partir da própria natureza fotográfica. 0 instante que foi captado pela câmera não poderá voltar a existir, de forma que a fotografia exibirá para sempre uma cena, pessoa ou paisagem que já não existe mais da mesma maneira, já foi alterada, e está, de certa forma, morta. Quando Barthes afirma que "o que a fotografia reproduz ao infinito só ocorreu uma vez: ela repete mecanicamente o que nunca mais poderá repetir-se existencialmente" (1984, p. 13), ele parece evidenciar tal correspondência entre a fotografia e a morte.

Sobre isso, se faz importante ainda destacar uma discussão feita por Giorgio Agamben sobre a museificação do mundo. De acordo com ele, o museu não é necessariamente um espaço físico ou um local específico, "mas uma dimensão separada para o qual se transfere o que há um tempo era percebido como verdadeiro e decisivo, e agora já não é" (2007, p. 73). Agamben explica que "tudo hoje pode tornar-se Museu, na medida em que esse termo indica simplesmente a exposição de uma impossibilidade de usar, de habitar, de fazer experiência" (2007, p. 73). Nesse sentido, percebemos que toda fotografia carrega em si essa característica de transferir aquilo que captura para uma esfera separada, onde já não se pode mais, utilizando as palavras de Agamben, "usar" aquilo foi fotografado da mesma maneira que se experimentava antes. Sontag explica, por exemplo, que já não conseguimos mais aproveitar cenas cotidianas da forma como fazíamos antes, pois o excesso de fotografias terminou por banalizá-las:

Certas glórias da natureza, por exemplo, foram simplesmente entregues à infatigável atenção de amadores aficionados da câmera. Pessoas saturadas de imagens tendem a achar piegas os pores do sol; agora, infelizmente, eles se parecem demais com fotos (SONTAG, 2004, p. 52).

Dessa forma, as pessoas fotografadas também parecem ser transpostas para essa esfera do sagrado, onde muitas vezes a relação que se estabelece com o retrato não é da mesma ordem daquela que era estabelecida com as pessoas ali retratadas. Basta pensar, novamente, na grande importância que algumas pessoas atribuem aos retratos de seus entes queridos falecidos, dando destaque a eles nas estantes, muitas vezes conversando com eles ou, até mesmo, virando o retrato de costas ao fazer alguma ação que a pessoa retratada reprovaria.

É nessa perspectiva que entendemos que o gesto do eu-lírico de "Os mortos" ao andar nu em frente aos retratos de sua família, é uma espécie de profanação, que de acordo com Agamben, é o ato de devolver ao nosso uso aquilo que tinha sido separado, restituir ao uso dos homens o que tinha sido elevado à esfera do sagrado. Se comumente, então, o retrato transforma a pessoa fotografada 
neste "objeto de museu", o eu-lírico drummondiano vai na contramão desse gesto, pois ao andar pelado em frente a elas, ele traz os retratos novamente para a esfera cotidiana, para o uso comum.

Movimento similar ocorre em "Os mortos de sobrecasaca", no qual o riso parece profanar o retrato, conforme podemos verificar na primeira estrofe do poema:

Havia em um canto da sala um álbum de fotografias [intoleráveis

alto de muitos metros e velho de infinitos minutos

em que todos se debruçavam

na alegria de zombar dos mortos de sobrecasaca (ANDRADE, 2007, p. 73).

Neste primeiro momento, os leitores do álbum demonstram certo desdém para com as fotografias - a expressão "mortos de sobrecasaca" por si só, já denota certo desajuste entre a expectativa do leitor e as pessoas retratadas, ao enfatizar um vestuário antiquado, fora de moda.

Na passagem para a segunda estrofe, contudo, podemos verificar que é certa atitude de zombaria dos espectadores em relação ao álbum que dá início ao segundo movimento do poema: "Um verme principiou a roer as sobrecasacas indiferentes" (ANDRADE, 2007, p. 73). Mais uma vez percebemos o gesto de afronta, nesse caso, a zombaria que profana essas fotografias e, assim, as restitui ao uso comum, à esfera humana. 0 verbo "principiar", neste contexto, é bastante significativo, pois revela que no momento em que as fotografias do álbum deixaram de ser da ordem do sagrado, elas acabaram sendo também relegadas ao esquecimento - simbolizado aqui por este verme que rói as páginas, as dedicatórias e até mesmo a poeira dos retratos.

Notamos, ainda, que nesse poema a fotografia localiza-se nesse lugar ambíguo em que o registro do passado, por si só, não garante acesso às memórias que foram, supostamente, impressas no papel, já que o verme parece também atuar como o agente que distancia o eu-lírico dos sentidos das fotografias, das memórias familiares que poderiam emergir através do álbum e, mais ainda, das pessoas ali registradas. Assim, o olhar que busca a memória mas encontra o verme, parece mostrar o entendimento que o eu-lírico faz da memória: falha e incerta, impossível de se apreender e se registrar em sua totalidade. É nesse sentido que Santiago afirma que "de nada adianta fazer perguntas à foto de família. A incomunicabilidade do plano real é duplicada no plano do simbólico" (2007, p. 29).

\section{Os mortos noticiados}

Já no poema "Os rostos imóveis", de José (1942), encontramos outro tipo de relação entre o eu-lírico drummondiano e a morte. Nesse texto, embora ainda haja o convívio com as pessoas mortas, que estão espalhadas por toda cidade, essa morte não parece mais ser literal, mas sim servir de metáfora para a mecanização da vida e o esvaziamento de sentido das coisas, conforme vemos na décima estrofe do poema:

Acordei e vi a cidade:

eram mortos mecânicos,

eram casas de mortos,

ondas desfalecidas,

peito exausto cheirando a lírios,

pés amarrados.

Dormi e fui à cidade:

toda se queimava,

estalar de bambus,

boca seca, logo crispada.

Sonhei e volto à cidade.

Mas já não era a cidade.

Estavam todos mortos, o corregedor-geral verificava etiquetas nos [cadáveres.

O próprio corregedor morrera há anos, mas sua mão continuava [implacável.

O mau cheiro zumbia em tudo (ANDRADE, 2007, p. 104). 
Esse poema, ainda que não verse especificamente sobre fotografia, traz elementos que fazem referências a fotos, começando pelo seu título, já que "rostos imóveis" podem pertencer tanto a pessoas mortas quanto a pessoas retratadas. Natalia Brizuela (2014) enfatiza que mesmo quando um texto poético não tem como temática a fotografia ou não incorpora imagens ao seu texto verbal, características da linguagem fotográfica podem ser encontradas nele de outra forma:

como paradigma de uma nova sintaxe e de uma nova literatura utilizando certas características do dispositivo fotográfico - como a indexicalidade, o corte, o ponto de vista, o pôr em cena, a dupla temporalidade (passado-presente/o que foi-o agora), o caráter documental, sua função mnemônica, o ser uma mensagem sem código (BRIZUELA, 2014, p. 31)

Notamos, em "Os rostos imóveis", que o ritmo, dado pela pontuação bastante marcada, é um desses elementos que dialoga com a linguagem fotográfica, já que remete ao longo do poema aos cliques constantes de um fotógrafo registrando acontecimentos rápidos, que após fazer uma foto, imediatamente aponta a câmera para o lado e registra o próximo movimento, a fim de não perder nada. Além disso, a forma como o poeta estrutura sintaticamente as situações que o eu-lírico vê na cidade, em sequências marcadas por versos curtos, sugere que esse eu poderia estar folheando fotografias, ou até mesmo as páginas de um jornal ilustrado por retratos acompanhando as últimas mortes noticiadas.

É importante destacar, nesse sentido, que esse poema foi publicado pela primeira vez em 1942, período social conturbado em que as notícias da guerra chegavam especialmente através dos jornais e dos telegramas. Dessa forma, o pensar e o fazer poético moderno foi também afetado por esses meios de comunicação. Walter Benjamin, ao refletir sobre o jornal, aponta-o como um exemplo da queda do valor da experiência na modernidade. De acordo com ele, o afastamento entre informação e experiência se dá pelo fato da informação não ter lugar na "tradição":

Walter Benjamin, ao diferenciar experiência (erfahrung) e vivência (erlebnis), vai definir a primeira como "a matéria da tradição, na vida coletiva como na privada" (2017, p. 107), ou seja, essa capacidade humana de dialogar e aprender com o passado. Capacidade essa que, na modernidade, começa a se esvair Segundo o autor: "está claro que as aç̃os da experiência estão em baixa, e tudo indica que continuarão caindo até que seu valor desapareça de todo" (1985, p. 198). Estamos mais ricos em vivências - ninguém pode negar a quantidade de situač̃es que vivenciamos diariamente - mas não conseguimos transfoct 列 essas vivências em experiências.

Letrônica | Porto Alegre, v. 12, n. 3, jul-set 2019: 32863
Historicamente existe uma concorrência entre as diversas formas de comunicação. Na substituição do antigo relato pela informação e desta pela sensação reflete-se a crescente redução da experiência. Todas essas formas, por seu lado, destacam-se da narrativa, que é uma das mais antigas formas de comunicação. Para ela, não era importante transmitir a pura objetividade do acontecimento, como faz a informação; integra-o na vida do contador de histórias para passá-los aos ouvintes como experiência (BENJAMIN, 2017, p. 109).

Em "Os rostos imóveis", vamos perceber, assim, um eu-lírico que demonstra certa dificuldade em se conectar com os acontecimentos e, especialmente, de sentir a morte que o cerca. De fato, nota-se nesse poema que os mortos não são mais os familiares do eu-lírico e não há uma rememoração deles ou uma busca de entendimento da morte e da memória a partir da fotografia. Há aqui determinado estranhamento, como se o poeta observasse os mortos à distância, justamente como quem observa fotografias de desconhecidos em um jornal, como fica explícito na terceira estrofe do poema:

Noiva morta, amigas mortas.

Chefe de trem morto, passageiro morto.

Irreconhecível corpo morto: será homem? bicho?

Cão morto, passarinho morto.

Roseira morta, laranjeiras mortas.

Ar morto, enseada morta.

Esperança, paciência, olhos, sono, mover de mão:

mortos (ANDRADE, 2007, p. 104).

Destacamos, no terceiro verso dessa estrofe, a presença de um "corpo morto", que o eu-lírico não consegue sequer reconhecer se é humano ou animal. Para a espécie de um corpo não ser reconhecível, esse possivelmente está mutilado ou deteriorado a ponto de perder as suas formas, mas o eu-lírico após visualizá-lo, apenas continua listando a série de outras coisas mortas que vê: animais, natureza e, por fim, também os sentimentos humanos, como 
a paciência e a esperança. Encontramos, dessa forma, em "Os rostos imóveis", um cenário em que a morte perde sentido e parece não mais afetar o eu-lírico.

Sobre isso, baseado em sua leitura do ensaio Além do princípio do prazer, de Sigmund Freud, Benjamin (2017) explica que determinadas vivências traumáticas ou violentas, chamadas de choques, são aparadas pelo nosso consciente, já que "quanto mais habitual se tornar o seu registro na consciência, tanto menos se terá de contar com um efeito traumático desses choques" (2017, p. 112). Assim, ao serem registrados no nível consciente, esses choques (vivências traumáticas) seriam incapazes de se tornarem experiências, já que, conforme explica Benjamin, para uma vivência se tornar experiência, ela precisa ser vinculada ao acervo da memória involuntária, aquela que não conseguimos acessar conscientemente, mas apenas através de algum estímulo, como um cheiro, um sabor ou um som. De acordo com o filósofo:

Só pode se tornar parte integrante da mémoire involuntaire aquilo que não foi "vivido" expressamente e em consciência, aquilo que não foi uma "vivência" para o sujeito. [...] Ainda segundo Freud, a consciência enquanto tal não registraria absolutamente nenhum registro da memória. Teria antes outra função significativa, a de agir como proteção contra os estímulos (BENJAMIN, 2017, p. 111).

Ao ler "Os rostos imóveis" a partir dessa perspectiva, percebemos um eulírico que vivencia esses choques de forma tão repetitiva - a palavra "morto", com suas variações de gênero e número, aparece 31 vezes durante o poema - que já não parece mais ser capaz de ser atingido por eles. Em suma, encontramos nesse poema o eu-lírico moderno descrito por Benjamin (1985), que ao mesmo tempo em que está repleto de vivências, está pobre de experiências, como podemos observar na décima estrofe, abaixo:

Olho meus pés, como cresceram, moscas entre eles circulam. Olho tudo e faço a conta, nada sobrou, estou pobre, pobre, pobre

mas não posso entrar na roda,

não posso ficar sozinho, a todos beijarei na testa,

flores úmidas esparzirei,

depois... não há depois nem antes.

Frio há por todos os lados,

e um frio central, mais branco ainda (ANDRADE, 2007, p. 104).

Evidenciamos ainda, na estrofe citada acima, como os modos de ver são fundamentais na construção dessa lírica, já que todas as reflexões realizadas pelo eu-lírico surgem a partir do seu olhar. Percebemos assim, mais uma vez, uma aproximação entre a linguagem poética e a linguagem fotográfica, já que os olhos do eu-lírico fazem recortes da realidade e partem de um detalhe ("Olho meus pés") na tentativa de apreensão do todo ("Olho tudo") o que resulta em frustração quando o poeta se dá conta da impossibilidade de capturar o todo, seja através do olhar, seja através da fotografia. De fato, o próprio poema parece ser uma tentativa de capturar um "todo", já que é um poema longo, com 66 versos, que se utiliza de muitas repetições, se tornando até mesmo redundante em alguns momentos.

Assim, na última estrofe do poema, quando o eu-lírico parece enfim encontrar alguma paz em meio ao caos que o circunda, essa paz é definida como uma "doce paz sem olhos" (ANDRADE, 2007, p. 105). Sant'Anna afirma que, em Drummond, "olhar, ver, contemplar, espiar são aqui sinônimos de conhecer, perceber, entender, revelando um processo metonímico comum na fala humana" (2008, p. 52). Nesse sentido, podemos inferir que para o eulírico desse poema, a paz seria aceitar o não entendimento e a dificuldade de apreensão da realidade. Essa aceitação, contudo, parece impossível para o poeta, já que ele só a atinge a partir de sua própria morte, quando no último verso, declara a "morte de mim e de todos" (ANDRADE, 2007, p. 105).

Dessa forma, embora "Os rostos imóveis" não esteja usualmente elencado entre os poemas drummondianos que estabelecem diálogo com o jornal ${ }^{8}$, vamos encontrar nele o questionamento sobre a capacidade desse tipo de meio de comunicação de dar conta de uma compreensão dos acontecimentos que vá além da mera descrição dos fatos.

8 Entre esses estão “O desaparecimento de Luísa Porto", “Morte do leiteiro”, “Poema do jornal” e “Notícias”, 
Destacamos ainda, nessa perspectiva, outro poema em que Drummond tensiona os mecanismos da informação ao noticiar mortes: em "Necrológio dos desiludidos do amor", de Brejo das almas (1934), o eu-lírico conta que aquilo que é mais notório sobre as mortes dos "desiludidos do amor" são as notícias que elas irão gerar:

\section{Os desiludidos do amor}

estão desfechando tiros no peito.

Do meu quarto ouço a fuzilaria.

As amadas torcem-se de gozo.

Oh quanta matéria para os jornais (ANDRADE, 2007, p. 59, grifo nosso).

Em seguida, no primeiro verso da segunda estrofe desse poema, o eu-lírico atribui importância à fotografia ao apontá-la como um objeto significativo do meio jornalístico que, de certa forma, confere às pessoas fotografadas fama e reconhecimento: "Desiludidos mas fotografados," (ANDRADE, 2007, p. 59), como se, mais relevante do que a desilusão, ou até mesmo, do que a própria morte, fosse o impacto que tais acontecimentos irão gerar ao serem noticiados. Dessa forma, esse poema, especialmente por causa de seu tom irônico, sugere também um esvaziamento de sentido que é propiciado pelos jornais e, em última instância, pelas fotografias. A crítica, entretanto, parece ser não à fotografia em si, mas a um funcionamento que, através do jornal diário - que tem como característica importante a rapidez na divulgação das informações, assim como, muitas vezes o sensacionalismo - culmina na banalização de imagens trágicas. Sobre isso, Sontag reflete que:

Numa era sobrecarregada de informação, a fotografia oferece um modo rápido de apreender algo e uma forma compacta de memorizá-lo. A foto é como uma citação ou uma máxima ou provérbio. Cada um de nós estoca, na mente, centenas de fotos, que podem ser recuperadas instantaneamente (SONTAG, 2003, p. 58).

A autora ainda declara que "Narrativas podem nos levar a compreender. Fotos fazem outra coisa: nos perseguem" (SONTAG, 2003, p. 243), indo ao encontro daquilo que o eu-lírico drummondiano está sugerindo no desenvolvimento desses dois poemas.

\section{Considerações finais}

A poesia de Drummond, promove uma reflexão sobre a possibilidade de se fixar e arquivar as experiências e as lembranças do passado, através da incorporação de elementos da linguagem fotográfica e de seus usos culturais. Quando essa experiência diz respeito à morte, a problematização das lembranças e do passado através dos retratos perpassa ainda a discussão sobre a permanência, a ausência e a família, temáticas também recorrentes na poesia de drummondiana.

Percebemos assim, a partir das análises propostas, duas abordagens diferentes realizadas por Drummond no que diz respeito à relação entre morte e fotografia. Na primeira delas, explorada no subtítulo "Os mortos profanados", o eu-lírico drummondiano faz uso das fotografias para elaborar a morte: elas são dispositivos da memória que auxiliam esse eu a rememorar os mortos, mesmo que essa rememoração não consiga ser completa ou seja interpolada por silêncios e vazios. Nos poemas "Os mortos" e "Os mortos de sobrecasaca", dessa forma, o poeta parece se utilizar da profanação como uma maneira de apontar a necessidade da problematização da função dos retratos de pessoas mortas. Agamben valoriza especialmente os atos de profanação, lembremos de sua célebre frase "A profanação do improfanável é a tarefa política da geração que vem" (2007, p. 79). Contudo, o movimento de profanação, nos poemas analisados, não tem somente os resultados positivos destacados pelo filósofo italiano, já que há também algo de inesquecível naquilo que é sagrado, uma vez que esquecer é uma característica humana. Assim, no momento em que os retratos são restituídos ao uso corriqueiro do homem, eles serão, inevitavelmente, esquecíveis e passíveis da deterioração do tempo, o que fica bastante evidente no álbum de fotografias roído pelo verme em "Os mortos de sobrecasaca". Ao mesmo tempo, ao restituir esses retratos à esfera humana, há também uma aproximação entre mortos e vivos, como podemos ver no tom de conciliação que "a ambígua intimidade" de "Os mortos" revela.

Em "Os rostos imóveis" e em "Necrotério dos desiludidos do amor", analisados na seção "Os mortos noticiados", o que vemos, contudo, é um poeta que já não é mais capaz de profanar, "de usar, de habitar, de fazer experiência" (AGAMBEN, 2007, p. 73). Essa impossibilidade, conforme destaca Agamben, é um sintoma de uma sociedade capitalista na qual o espetáculo é a regra e, segundo o autor, "espetáculo e consumo são as duas fases de uma única impossibilidade de usar" (2007, p. 71). As fotografias, 
nesse contexto, ao passarem da esfera pessoal para a esfera do jornal, se tornam sensacionalistas e incapazes de promover uma leitura sensível de mundo, não conseguindo assim comover o eu lírico que acaba por banalizar a morte e o suicídio.

Essa abordagem dupla, entretanto, não parece ser uma questão temporal, pois se assim fosse, os poemas que foram publicados mais tarde, quando o capitalismo ficou mais fortalecido, teriam esse olhar mais pessimista em relação aos usos da fotografia. Esse não é o caso, já que "Necrotério dos desiludidos do amor", foi publicado em 1934, enquanto "Os mortos" é de 1962, por exemplo. A variação nos modos de interpretação dos usos fotográficos parece antes ter mais a ver com uma personalidade drummondiana característica de "um poeta de sete faces", fundador de um olhar gauche que oscila - basta ver, por exemplo, as diferenças entre o lirismo esperançoso de A Rosa do Povo e o poeta de Claro enigma, publicado menos de uma década depois, em que o poeta estava entediado pelos acontecimentos 9 . Ao pôr em evidência as fissuras do dispositivo fotográfico, todos os poemas analisados enfatizam ainda determinada melancolia e pessimismo, características mais uma vez associadas a um sujeito à esquerda dos acontecimentos.

\section{REFERÊNCIAS}

AGAMBEN, Giorgio. Elogio da profanação. Profanações. Trad. Selvino J. Assmann. São Paulo: Boitempo, 2007.

ANDRADE, Carlos Drummond de. Poesia completa. Rio de janeiro: Nova fronteira, 2007.

BARTHES, Roland. A câmara clara. Trad. Júlio Castañon Guimarães. Rio de Janeiro: Nova Fronteira, 1984

BENJAMIN, Walter. Experiência e pobreza. Magia e técnica, arte e política: ensaios sobre literatura e história da cultura. Trad. Sérgio Rouanet. São Paulo: Brasiliense, 1985. (Obras Escolhidas, v. 1.).

BENJAMIN, Walter. Sobre alguns motivos na obra de Baudelaire. Baudelaire e a modernidade.

"Les événements m'ennuient" ("Os acontecimentos me entendiam"), verso de Paul Valery usado como epígrafe no livro Claro Enigma (1951)

Letrônica | Porto Alegre, v. 12, n. 3, jul.-set 2019: e32863
Trad. João Barrento. Belo Horizonte: Autêntica Editora, 2017.

BENJAMIN, Walter. Estética e sociologia da arte. Trad. João Barrento. Belo Horizonte: Autêntica Editora, 2017.

BLUME, Sandro. Fotografia mortuária e imagens da boa morte. Revista Brasileira de História das Religiões. Maringá, v. 5, n. 15, p. 1-15, 2013.

BRIZUELA, Natalia. Depois da fotografia: uma literatura fora de si. Trad. Carlos Nougué. Rio de Janeiro: Rocco, 2014.

DIDI-HUBERMAN, Georges. 0 rosto e a terra: onde começa o retrato, onde se ausenta o rosto. Porte Arte Revista de Artes Visuais. Trad. Sonia Taborda. Porto Alegre: v. 9, n. 16, p. 61-82, 1998. https://doi.org/10.22456/2179-8001.27751

DIDI-HUBERMAN, Georges. A imagem queima. Trad. Helano Ribeiro. Curitiba: Medusa, 2018.

FONTCUBERTA, Joan. O beijo de Judas: fotografia e verdade. Trad. Maria Alzira Brum Lemos. Barcelona: Gustavo Gili, 2010.

FONTCUBERTA, Joan. A câmara de Pandora: a fotografia depois da fotografia. Trad. Maria Alzira Brum Lemos. Barcelona: Gustavo Gili, 2010. E-book. kindle edition.

KOSSOY, Boris. Os tempos da fotografia: o efêmero e o perpétuo. 3. ed. rev. São Paulo: Ateliê Editorial, 2014

SANTIAGO, Silviano. Introdução à leitura dos poemas de CDA. In: ANDRADE, Carlos Drummond de. Poesia completa. Rio de Janeiro: Nova fronteira, 2007. p. (III-XLI).

SONTAG, Susan. Diante da dor dos outros. Trad. Rubens Figueiredo. São Paulo: Companhia das Letras, 2003. E-book. Kindle edition.

SONTAG, Susan. Sobre fotografia. Trad. Rubens Figueiredo. São Paulo: Companhia das Letras, 2004. E-book. Kindle edition.

VAILATI, Luiz. As fotografias de "anjos" no Brasil do século XIX. Anais do Museu Paulista, São Paulo. N. Sér. v. 14. n. 2, p. 51-71, jul./dez. 2006. https://doi.org/10.1590/S0101-47142006000200003 